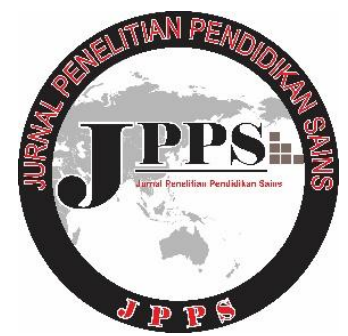

JPPS (Jurnal Penelitian Pendidikan Sains)

p-ISSN: 2089-1776

e-ISSN: $2549-1597$

Volume 7, No.2, Mei 2018

https://journal.unesa.ac.id/index.php/jpps/index

\title{
DEVELOPMENT OF CHEMISTRY INSTRUCTION MATERIAL USING PROBLEM BASED LEARNING MODEL FOR INCREASING THE STUDENT OF SENIOR HIGH SCHOOL LEARNING ACHIEVEMENT
}

\author{
Robiatusy Syifaiyah $^{1 *}$, Tukiran ${ }^{1}$, dan Erman ${ }^{1}$ \\ 1) Postgraduate Science Education, Universitas Negeri Surabaya, Indonesia \\ *E-mail: Robiatusy_Syifaiyah@yahoo.co.id
}

\begin{abstract}
This research aims to develop chemistry learning materials PBM models oriented in curriculum 2013 to improve learning outcomes of high school students on the material factors that affect the rate of reaction. This research is the development by using Kemp models,et al. Limited trial design uses one group pretest posttest design with descriptive analysis techniques of quantitative and qualitative descriptive. This study uses the subject of the trial class XI SMA-Based Leading Pesantren Amanatul Ummah 2015-2016 school year on the subject of factors that affect the rate of reaction. The results showed: (1) The quality of the device can be seen from the validation RPP, validation BAS, validation worksheets, and validation of THB categorized either by reading level easily understood, (2) practicality of the device can be seen from Keterlaksanaan RPP categorized very well, (3) Effectiveness learning tools can be seen from the thoroughness of individual student learning outcomes and the traditional, the effectiveness is also supported by the positive response of students to study indicated $95.83 \%$ of students who give a positive response. Based on data analysis can be concluded that the learning device by problem-oriented in curriculum 2013 on material factors that influence the reaction rate meets the criteria of quality, practicality, and effectiveness so that used in learning.
\end{abstract}

Keywords: MPBM and Curriculum 2013

\section{INTRODUCTION}

The effort of increasing the education quality must be done by working elements that are the education system. The first subsystem to increase the education quality is teacher role. Teacher has main role to lead the instruction at class as the most dominant information facilitator to students (Suprijono, 2010). Teacher gives chance to student for learning by participating actively in the instruction. The effective learning condition is when the students have interest and attention to learn (Slameto, 2010). So, teacher must have the professional competency to handle it.

At this time the instruction materials have not be enough to cover activities that involve the students because it lacks of challenge activity. Although the reshuffle paradigm of education along with the science and technology advancement starts from using the pedagogic approach and then suggested to use androgogic approach in Kurikulum 2013 instruction (Mulyasa, 2013). This approach contains the meaning of androgogic that place the role of students more dominant in the instruction. Besides, it places the attention of each students intactly. The learning process that using Kurikulum 2013 for all grades will be implemented by applying scientific approach. The steps of scientific approach in the learning process cover activities such as excavating information through observing, asking, 
practicing, processing data, presenting data, analyzing, reasoning, concluding, and creating (Kemendikbud, 2013).

Using of the instruction materials with implementing scientific approach is expected can give positive contribution, that is the learning achievement of Senior High School students increasing. In order that the instruction materials have good concept, so the material can be developed by using the istruction model that lead students participate actively One of instruction models that may be increase the participation of students is problem based learning.

Problem Based Learning is the instruction that has a goal to work cooperatively and be led by a teacher (Suprijono, 2009). Beside that, this instruction is arranged as an effort to increase participation, facilitate students by leadership and making decision in a group, and give a chance to interact and learn together with different background. Problem based learning model also emphasize to communicate and interact each other in the learning process (Slavin, 2008). Teacher of SMA Unggulan Berbasis Pesantren Amanatul Ummah is less interested to use Problem Based Learning model because teacher feels difficult to handle the students in a group for a long time to encourage students to get the information that is needed.

Based on the result of observation at SMA Unggulan Berbasis Pesantren Amanatul Ummah stated that students were looked passively while the learning process. Students more like being silent and only listening what teacher explained. Students were considered not interested and not understand about the lesson which was teached by teacher. This condition affected students to follow the teacher did and tend to memorize, so it was difficult to reach the learning achievement improvement. This statement was supported based on the questionnaire which was given by researchers to students of SMA Unggulan Berbasis Pesantren Amanatul Ummah. It stated that $75 \%$ students who occurred the study difficulties within learning chemistry, it was caused by the result of percentage $81,25 \%$ students who stated that chemistry was not interesting, so the learning achievement decresed.

Based on the questionnaire which was given to teachers of SMA Unggulan Berbasis Pesantren Amanatul Ummah showing 87,2\% teachers stated that knew problem based learning but did not apply it at class. Another question was what teachers know scientific approach did. It showed $79,5 \%$ teachers knew scientific approach but they did not know what ability they need to have while applying scientific approach at class. From the collected datas represented that teachers need to be given the knowledge about how to develop the instruction materials of learning chemistry using problem based learning to increase the students learning achievement.

Teachers had motivated students to be more active while learning at class by giving the additional score from students activities. Students were not active at all. Some students were still activeless to learn at class. Remembering the condition caused the way to deliver the matter must adjust with the learning characteristic that demand students to participate actively at class. Every new matter has a connection with other knowledge from other matters or subjects and past experience which students had (Arends, 2009).

The factors which affect the reaction rate is very exact to be learnt by doing experiment or laboratory work. Concepts of reaction rate factors were difficult to be understood by students if the matter was only teached verbally without giving the experience of doing experiment. Therefore the matter of reaction rate factors was suitable based on Kompetensi Dasar (KD) which contained to analyze the factors which affect the reaction rate and determine reaction orde following the data of their experiment results, so it must be informed to students while teachers teach them at class. Its matter topic will cause students facing many problems about factors which affect the reaction rate in the daily life, so students feel more challenge to give solutions to overcome the daily problems. Pada materi laju reaksi siswa akan dihadapkan. Every students were active to construct concepts by applying scientific approach. Scientific approach has some steps, there are observing, explaining, and concluding the problems which had been observed by students. This learning condition was agreed according to scientific approach which was process of learning that was arranged so thet make students more active to construct concepts, laws or principles by doing the steps of scientific approach such as observing (to identify or find the problems), collecting datas by using various technic, analyzing datas, concluding, and communicating the concepts which was found by students while doing experiment. According to explaining statements above, the researcher will do research about developing the chemistry instruction materials which using Problem Based Learning to increase the students learning achievement.

\section{METHOD}


This research was the developmental research. It was caused by developing the instruction materials of chemistry learning using problem based learning to increase the learning achievement of senior high school students to implement at school.

\section{RESULT AND DISCUSSION \\ A. Validity of Instruction Materials \\ 1. Lesson Plan Validity}

Lesson plan or Rencana Pelaksanaan Pembelajaran (RPP) was developed as the teacher guidance of managing the learning process problem based learning oriented to increase concepts of reaction rate factors which was informed four times by teacher.

The result of data validity in Table 4.2 showed that developed RPP had average score $=$ 3,74 . That RPP was valid to be applied in learning reaction rate factors using problem based learning to increase the student understanding about concepts of factors which affect the reaction rate was related concistently and be nice category. Based on Table 4.1 we could know that the appropriateness between learning approach which was chosen and the learning goals which was gained hopefully. It was gained because of constructing RPP based on Permendiknas No.65 Tahun 2013 about Standar Isi that contains the guidance of arrangement syllabus and lesson plan (RPP). Besides the developed RPP was also appropriate with steps of problem based learning.

RPP assessment quality completeness was assessed good. It was caused by developing this instruction materials which was stated by BSNP (2007). Besides, discussing with teachers also one of factors to become RPP good assessment, so RPP was developed appropriate with steps of arranging RPP and steps of problem based learning. RPP format which was developed by researcher according to Permendiknas 41 Tahun 2007. There were subject identity (school name, class, subject, semester, allocation, and time), competency standard (SK), basic competency (KD), indicator, and learning goals, matter, learning model, learning activity (preface, core activity, conclusion), assessment, and source of learning.

According to Ibrahim (2010) steps of arranging RPP are (1) giving identity, such as school name, and indicator was cited from syllabi, time allocation need to be estimated precisely for learning goals completeness; (2) attaching indicator which was explained by teacher from basic competency (KD). Every indicator consists of two parts that are behavior that are behavior and learning content; (3) attaching learning goals which contains competency mastery operationally for reaching the learning goals; (4) attaching learning matter that is used for reaching the goals of learning subject matter is developed by following the main matter in syllabi; (5) attaching learning model that could be meant as chosen learning strategy which would be applied at class; (6) attaching steps of learning process that are preface, core/ main activity, closing which all follow the syntax of chosen learning model; (7) attaching learning source that cover reference, environment, media, keynote speaker, tools and materials, learning source is written more operationally; and (8) attaching assessment, that is explained of assessment technic, instrument form, and used instrument to get the data.

\section{Student Textbook Validity (BAS)}

Student textbook (BAS) contains the matter description as students learning guidance or learning source for understanding reaction rate factors topic in the learning process at class. The appropriateness assessment of BAS showed the average of validity assessment score which was given by validators was 3,57 .

This research result showed that developed BAS was appropriate to be students guidance book for students and teachers in the learning process using problem based learning model to increase students concept understanding although it got few things of revision. Revision of BAS validity was layout error, error image placement, and image source attachment. This developed textbook had the concept of rate reaction factors topic.

The completeness of BAS quality with good category was caused the developed BAS had been appropriate of the steps developing its textbook based on BSNP (2006). Developing of BAS which applied BSNP (2006) considered some things: (1) Information processing strategy in BAS must be meaningful information of the topic which students learn, have the high readability, interesting, the content has an ability to optimilize the students mind; (2) students psycoscocial development level was developing BAS and concerning toward the cognitive development level and reader emotional social like difficulties of majoring the concepts, ability and familiarity of language; (3) Active learning process which was BAS presentation concerning the connection of the real life so that it can encourage students to implement the information which they get at class during learning process to become the students more creative and innovative. 
According to Nur (2008) in generally the steps of developing BAS are: (1) identifying the aspects which have sthe competency standard and basic competency which became as a guidance or reference in developing learning matter; (2) identifying the types of learning materials; (3) selecting instructional materials that are relevant or relevant to the standard of competence and basic competency indicated earlier; and (4) selecting the source of learning materials and subsequently compiled the learning materials.

In general, the purpose of this textbook development is to enable students to learn in stages to be able to master the competence on the concept of factors that affect the rate of reaction and become a tool of students in the mastery of knowledge and improvement of students' conceptual understanding.

\section{Students worksheet (LKS) validity}

The Student Activity Sheet (LKS) developed is a guide for students to carry out the learning activities. LKS developed consists of LKS 1, LKS 2, LKS 3, and LKS 4. LKS 1 contains about the effect of reaction rate on concentration, LKS 2 contains about the effect of reaction rate on concentration, LKS 3 contains about the influence of reaction rate to temperature, and LKS 4 contains the effect of reaction rate on the catalyst. Based on Table 4.8 the assessment results by the validator against the developed LKS has an average score of 3.51. Thus, the LKS developed is categorized well and feasible to be used because it fulfills the aspects of validity and relates consistently. The LKS is planned to help students learn about the basic concepts presented during group discussions. The purpose of these experimental activities is to help students divert abstract concepts into real experiences. This is in accordance with the opinion of Simamora (2012) which states that the objects and natural events must be a little by doing experiments and observations and sought explanation through the process of thinking to get the reasons and arguments.

Achievement of LKS quality that developed with good category, because in accordance with structure of LKS component based on BSNP (2007). According to BSNP (2007), the Student Activity Sheet is a sheet that contains the tasks that should be done by the students used as a means to optimize learners' learning outcomes and increase the involvement of learners in the learning process. The structure of LKS is (1) as the title; (2) work instructions; (3) competence to be achieved; (4) supporting information; (5) task work steps. According to Nur (2008) which characterizes good LKS at least contains several things, namely: (1) LKS can help students find the concept; (2) LKS can help students apply and integrate various concepts that have been found; (3) LKS can serve as instruction guides; (4) LKS serves as a reinforcement; and (5) LKS serves as a practice manual.

\section{Learning Achievement Test Validity (THB)}

Learning achievement test was used as an evaluation to assess the student learning achievement increasing in mastery concepts which was given during the learning process. The validation result is shown on the Table 4.7. the learning achievement test which was developed in this research was multiple choice. It had five options A, B, C, D, and E on the test sheet. The learning achievement test was arranged for assessing the student competency in understanding concept of the reaction rate factors. According to Validator, it had weaknesess on the test sheet, such as some question needed to be straightened between the indicator and its question. After observing and following up suggestion and revision from lecturers and validators so that the learning achievement test can be used to learn reaction rate factors at Senior High School.

\section{B. Textbook and The Student Worksheet Readability}

The readability of students textbook was gained from the result of students assessment toward student textbook readability using questionnaire. The result of BAS and LKS can be seen on the Table 4.9 and Table 4.10 based on data analysis result which was gained $70 \%$ stated the students were positive toward BAS and LKS so it could be concluded that BAS and LKS were interesting for students although some students had difficulties. The figure or illustration that we can describe the readability essay of BAS and LKS generally categorized good and valid was applied in the instruction. The readability was caused based on the assessment standard of BAS and LKS according to Nur (2008) who explained that aspect of language or readability, such as (1) using Bahasa based on the rules of Indonesia Language spelling (EYD), (2) terminology, (3) Indonesia Language clarity, (4) Indonesia Langugae appropriateness, (5) the readability ease.

\section{The instruction materials implementation \\ 1. The instruction materials implementation \\ The lesson plan (RPP) implementation can be} seen from the result of implementation 
assessment that was given by 2 observers. Observing toward the instruction implementation had a goal to know the success of teachers within applyin the steps of lesson plan so it could be assessed its effectiveness in the last instruction. Observation in the beginning of instruction was found the teacher started the instruction without praying, motivating students with giving the real phehnomenon, and communicating the instruction goal. In this case, teacher motivated students to concern during instruction was held by giving goals of instruction and describing the real life phenomenon so the students can grow curiousity that can be observed from assessment of lesson plan (RPP).

In the main phase, in which teachers give the short information about the matter that will be learnt. Then teacher divided students in a group, gave BAS and LKS, and excercised students by applying problem based learning that had lab working that must be finished by students showing good category of RPP while they discussed and presented the result in a group. Problem based learning is the instruction model that lead the students to express their ideas and cooperate with each other to finish the assignment by respecting each other in everything they did during the instruction. In the class of instruction, teacger guide students to make a conclusion. From the class situation it can be mentioned that instruction was suitable problem based learning syntax and learning goals that wanted be reached. during which KBM tends to be student-centered, where each phase in the learning is organized in such a way that the student can master the competencies to be achieved by playing an active role. The average observation result of the overall learning done by the observer in the classroom atmosphere is included in the good category.

Based on the observation of the implementation of the Lesson Plans (RPP), it can be concluded that the steps in the RPP are well implemented because the average score given by the observer is $100 \%$. In general, the syntax of learning can be implemented so that learning tools developed provide convenience for teachers in implementing learning and provide convenience for students to successfully complete the learning.

\section{Students response}

Student response data to the components of Chemistry learning activities with Problem Based Learning model were collected through questionnaire. Based on the results of the questionnaire analysis of student responses can be stated that some students respond to learning. Results Questionnaire response students, the question of how the students' opinions on the subject matter, BAS, LKS, how to teach the learning environment dilatihkan teachers, and stages directed in the learning process of $98.5 \%$ of students who answered interesting. This indicates that the Problem Based Learning model makes students interested in learning chemistry.

Result of questionnaire of student response, on question whether student feel new to component of LKS, BAS, learning atmosphere which trained by teacher, and way of teaching teacher equal to $96,25 \%$ student answer new and $3,75 \%$ student answer not new. This indicates that the components used in the process of Problem Based Learning is a new thing.

Result of questionnaire of student response, to question whether student feel new to component formulate problem, formulate hypothesis, determine experiment variable, do experiment, analyze data, and make conclusion equal to $91,67 \%$ student answer new and $8,33 \%$ student answer not new. Some of the students who answered were not new to the component doing experiments, analyzing data, and making conclusions. Teachers at school once invited students to do practicum activities.

The result of questionnaire of student response, to question whether students are happy to component formulate problem, formulate hypothesis, determine experiment variable, do experiment, analyze data, and make conclusion equal to $99 \%$ student answer happy and $1 \%$ answer unhappy student.

The result of questionnaire of student response, on the question of whether the student can easily follow the components of formulating the problem, formulating the hypothesis, determining the experimental variable, conducting experiments, analyzing the data, and making conclusions as much as $95 \%$ of students answered easily and 5\% students answered is not easy. It identifies that students easily follow the learning process with Problem Based Learning model.

Result of questionnaire of student response, on question whether student interest to follow learning with model of Problem Based Learning in next learning 94\% student answer interested. Problem Based Learning model is very interesting student interest to follow the next lesson.

Based on the result of questionnaire analysis of student response can be stated that most of student respond to study of Chemistry with Problem Based Learning model to improve 
student learning result as interesting and new learning. Students give a very positive response to the learning of Chemistry with Problem Based Learning model to improve student learning outcomes, can be seen from the percentage of the number of students who stated positive value in every aspect $\geqslant 70 \%$. Interest in teaching materials, Student Handbooks, and Student Activity Sheets of interest in learning are excellent for motivation. According to the theory of motivation, interest and the interests of students on learning can increase student motivation. In the beginning students feel difficulty in carrying out practicum at the time of learning. But after being involved in learning, students feel the ease in implementing these components. In addition, the learning has made students able to do the comprehension test. In general, students give a very positive response to the learning of chemistry with Problem Based Learning model on the matter of Factors Affecting Rate of Reaction. This positive response in accordance with the expectations of Chemistry learning in general that Chemistry learning should be able to increase belief in God Almighty, develop an understanding of the importance of applying Factors that Affect the Rate of Reaction in everyday life, act scientifically, and communicate.

\section{Learning achivement}

This test is done to know the mastery of the students concept of the concepts given during the learning. The concept comprehension test used is a multiple choice test with 20 items of questions including knowledge test (cognitive). The test is done twice before (pretest) and after (posttest) learning. The result of value analysis obtained by students after taking concept comprehension test is presented in Table 4.14.

Minimum Exhaustiveness Criterion (KKM) in SMA Unggulan Pesantren Amanatul Ummah determined by SMA Chemistry teacher is 80 . Based on Table 4:14 before the chemistry learning on the material reaction rate with the learning model based on the problem obtained the results of learning with individual completeness has not been completed. After implemented the learning by using Problem Based Learning model by using Student Handbook (BAS) and Student Activity Sheet (LKS) which has been developed value obtained by students in classical equal to $81,41 \%$. The success of students in teaching lessons is caused by several things, namely: (1) the availability of the main learning tools, which include: LKS, BAS, and good assessment sheet, this is supported by the validation of learning devices that obtain good category; (2) ease of teachers in the implementation of learning so that learning can take place well; and (3) active student involvement in learning. Based on student activity data, it is found that the dominant student activity is to experiment, cooperate among groups, ask questions, express opinions and respond to and appreciate the opinions of friends / groups. The activity shows that the learning activities are student-centered. Such learning enables students to actively build their own knowledge, teachers only act as facilitators; (4) Positive responses of students, ie students declare that teaching materials, BAS, LKS and learning atmosphere including interesting and new, students are interested with applied learning methods, students feel helpful in digging and processing information effectively, efficiently, creatively, and students also feel easy in answering items. Based on the theory of motivation, positive student response is very important both intrinsic motivation in the form of teaching materials, BAS, LKS, learning atmosphere and extrinsic motivation. Based on Table 4.14 there is also one unfinished student whose value is less than 80 . The unfinished student is due to less actively involved in learning sehinnga response to learning especially on learning less / low chemistry, difficulty in learning because of low ability level, leading to a lack of understanding of teaching materials, as evidenced by the interviews and the list of grades given by Chemistry teachers. Therefore, this unfinished student will get remedial until it gets the value according to the minimum criterion value that is $>80$. Bruner (in Carin, 1993) claims that the learner is not a mere listener. She believes that children learn best if students are actively involved in learning.

Based on Table 4.16, the result of the completeness of the indicator at the pretest and posttest that can be briefly described that for the cognitive test when the pretest of the completed indicator is $0 \%$ and at the posttest indicates that from 20 indicators there is no unfinished indicator. Based on Table 4:17 which consists of 20 items the question shows all the items either. Based on the students' understanding of the concept before and after the learning with Problem Based Learning model found that the increase of knowledge mastery score is significant where the correct answer of the students on the correct answer of the students on the posttest has increased. This proves that the learning process is done well. Meanwhile, based on the results of the calculation of the score increase (gain score) can be stated that the score increase is classified as having a score of 0.70 or 
$70 \%$ of 0.76 or $76 \%$. This shows that the scientifically oriented Problem Based Learning model applied in the learning of matter Factors Affecting Rate of Reaction can improve student learning outcomes significantly. The results of this study are supported by the previous studies results (Prahani, et al., 2015; Prahani et al., 2016; Prahani, et al., 2018; Sudiarman et al., 2016; Yasir, et al., 2016) that the teaching materials, devices, and learning models of quality and feasible (meet the valid, practical, and effective aspects) can improve student learning outcomes.

The achievement of the quality of the concept comprehension test with good category is due to the test developed according to the Regulation of Permendiknas number 20 of 2007 (BSNP, 2007) that: The instrument of assessment of learning outcomes used by the educator should meet the requirements (a) the substance is presenting the assessed competence, (b) is to meet the technical requirements in accordance with the instruments used, and (c) the language is to use good and correct language and communicative in accordance with the level of development of learners.

Based on the results of research on the understanding of the concept that has been described above, that there is an increased understanding of the concept in learning with the model of Problem Based Learning because learning with Problem Based Learning model improves student learning outcomes so that knowledge and skills obtained by students through the process of investigation will be easier to remember. This is supported by the statement of Amaliah (2008) that the improvement of conceptual mastery can occur because Problem Based Learning can participate in the search of the concepts studied so that the resistance to the concept will be longer than the concept of teacher explanation.

Umrotun (2012) states that the model of Problem Based Learning can change the behavior of learners in understanding the concept. Learning with Problem Based Learning model can improve student learning outcomes, as summarized by (Bukhori, 2012) in his research that model of Problem Based Learning can improve student learning outcomes, improve teacher competence and develop good behavior related to changes in student learning outcomes.

\section{CONCLUSION}

Based on the findings of the research results in Chapter V, they are: (1) learning tools with Problem Based Learning model including RPP,
BAS, and LKS developed to improve student learning outcomes on the material Factors affecting reaction rate fulfill the element of validity; (2) Learning tools with problem-based learning model developed to improve student learning outcomes on the material Factors affecting reaction rate meet the elements of effectiveness; (3) Learning device with problembased learning model developed to improve student learning outcomes on the material Factors affecting reaction rate satisfy the element of practicality. Then it can be concluded that the learning device with Problem Based Learning model developed by using model Kemp et al feasible used to improve student learning outcomes on the material Factors that affect the rate of reaction.

\section{Suggestion}

Some suggestions can be put forward by researchers based on the implementation of research conducted is as follows:

1. To support the process of implementation of learning with Problem Based Learning model on the material Factors that affect the reaction rate at high school level, especially SMA Unggulan Pesantren Amanatul Ummah Pesantren. Teachers can use the tools they have developed.

2. In planning and implementing the learning with the model of Problem Based Learning should teachers prepare experimental tools that will be used with great care, so the investigation can run smoothly.

3. Giving the feedback of the student's response to learning positively Problem Based Learning model, it is expected that this model will be applied to other chemistry teaching materials.

\section{REFERENCES}

Atkins, P. and Paula, J. (2006). Physical Chemistry (Eighth Edition). New York: W. H. Freeman and Company.

Auliana. (2008). Komponen-komponen pengembangan kurikulum. Jurnal FMIPA UPI. 1(1).

Doabler, C. (2011). Using a scientific process for curriculum development and formative evaluation: Project Fusion. The Journal of Conference abstract tamplate. 1(7).

Herman, T. (2007). Pembelajaran berbasis masalah untuk meningkatkan kemampuan berpikir matematis tingkat tinggi siswa sekolah menengah pertama, 1(1).

Prahani, B.K., Nur, M., Yuanita, L., and Limatahu, I. (2016). Validitas model 
pembelajaran group science learning: Pembelajaran inovatif di Indonesia. Vidhya Karya, 31(1), 72-80.

Prahani, B.K., Suprapto, N., Suliyanah, Lestari, N.A., Jauhariyah, M.N.R, Admoko, S., and Wahyuni, S. (2018). The effectiveness of collaborative problem based physics learning (CPBPL) model to improve student's self-confidence on physics learning. Journal Physics: Conference Series, 997(1), 012008.

Prahani, B.K., Soegimin, W.W., and Yuanita, L. (2015). Pengembangan perangkat pembelajaran fisika model inkuiri terbimbing untuk melatihkan keterampilan penyelesaian masalah berbasis multi representasi siswa SMA. Jurnal Penelitian Pendidikan Sains, 4(2), 503-517.

Slameto. (2003). Belajar dan faktor-faktor yang mempengaruhinya. Jakarta: Rineka Cipta.

Sudiarman, Soegimin, W.W, and Susantini, E. (2015). Pengembangan perangkat pembelajaran fisika berbasis inkuiri terbimbing untuk melatihkan keterampilan proses sains dan meningkatkan hasil belajar pada topik suhu dan perubahannya. Jurnal Penelitian Pendidikan Sains, 4(2), 636-647.

Sugiyono. (2011). Statistika untuk Penelitian. Bandung: Alfabeta.

Suyono dan Hariyanto. (2011). Belajar dan Pembelajaran. Bandung: Remaja Rosda Karya.

Yasir, M., Ibrahim, M., and Widodo, W. (2016). Pengembangan perangkat pembelajaran biologi berbasis metakognitif untuk melatihkan kejujuran siswa. Jurnal Penelitian Pendidikan Sains, 5(2), 11091015. 